\title{
Modeling Cost Saving and Innovativeness for Blockchain Technology Adoption by Energy Management
}

\author{
Nazir Ullah ${ }^{1, *(D)}$, Waleed S. Alnumay ${ }^{2}$ D, Waleed Mugahed Al-Rahmi ${ }^{3}$, \\ Ahmed Ibrahim Alzahrani ${ }^{2}\left(\mathbb{D}\right.$ and Hosam Al-Samarraie ${ }^{4}$ \\ 1 School of Management and Engineering, Department of Management Science and Engineering, \\ Nanjing University, Nanjing 210093, China \\ 2 Computer Science Department, King Saud University, Riyadh 11437, Saudi Arabia; \\ wnumay@ksu.edu.sa (W.S.A.); ahmed@ksu.edu.sa (A.I.A.) \\ 3 Faculty of Social Sciences and Humanities, School of Education, Universiti Teknologi Malaysia, \\ Johor Bahru 81310, Malaysia; waleed.alrahmi@yahoo.com \\ 4 School of Media and Performing Arts, Coventry University, Coventry CV1 5FB, UK; \\ h.alsamarraie@coventry.ac.uk \\ * Correspondence: nazirabaz@gmail.com
}

Received: 19 July 2020; Accepted: 17 August 2020; Published: 14 September 2020

\begin{abstract}
In developed nations, the advent of distributed ledger technology is emerging as a new instrument for improving the traditional system in developing nations. Indeed, adopting blockchain technology is a necessary condition for the coming future of organizations. The distributed ledger technology provides better transparency and visibility. This study investigated the features that may influence the behavioral intention of energy experts to implement the distributed ledger technology for the energy management of developing countries. The proposed model is based on the Technology Acceptance Model construct and the diffusion of the innovation construct. Based on a survey of 178 experts working in the energy sector, the proposed model was tested using structural equation modeling. The findings showed that perceived ease of use, perceived usefulness, attitude, and cost saving had a positive and significant impact during the blockchain technology adoption. However, innovativeness showed a positive effect on the perceived ease of use whereas an insignificant impact on the perceived usefulness. The present study offers a holistic model for the implementation of innovative technologies. For the developers, it suggest rising disruptive technology solutions.
\end{abstract}

Keywords: adoption theories; DLT; energy sector; blockchain; TAM

\section{Introduction}

Digitalization and technological development is the backbone for economic growth and environmental sustainability for any country [1]. All the countries of the world are adopting modern ways and technologies to rival each other and get work done in a paramount strategic way. Innovations and technological adoptions are very much essential for the economies to retain their business and achieve the targets [2]. The energy sector of any country is the crucial one to accomplish efficiency and fulfill the demand of the country and its residents [3]. Worldwide energy consumption and energy requirements anticipate an increase to 28\% from the year 2015 to 2040. In the case of the Asian region, the expected rise of energy will be $51 \%$, which is the highest among the other regions of the world [4]. Currently, worldwide renewable energy production is highly focused, and developing countries are also moving toward the proper implementation of renewable energy solutions. Presently, developing countries are facing serious problems in the production and distribution of energy. In such 
countries, millions of people are affected by the energy crisis, and presently, it is a big challenge to meet the energy needs of both the industry and residential sectors [5]. So, the advent of disruptive technology in developed states for energy management is emerging as a paradigm to improve the traditional energy system in developing states. The use of distributed ledger technology as renewable energy will have a substantially significant effect on energy's sustainable usage by offering greater convenience for the customer. The distributed ledger technology can be useful in the energy sector for carbon management, distributed trading, and the popularization of renewable energy [6]. Specially, distributed ledgers can aid in lessening transaction costs and enhancing the flexibility in energy project funding developments [7]. The blockchain can provide better privacy for transaction within the energy wholesale trading phase [8]. Moreover, distributed ledgers can improve the clearing settlement mechanism in retail trading practice, promoting community involvement in the procurement cycle in new energy use and in the reduction of carbon emissions [9].

Indeed, innovation in technology is a critical engine of energy transitions. One such breakthrough is the smart grid. Consequently, turning in developments in the digital industry is beneficial [10]. According to [11], "the technology revolution reverses the industrial revolution and in this way changes the structure of the markets". The payment system is experiencing remarkable change, with an increase in cashless associations, P2P transactions, and social networking micropayments [12]. The marketplaces are gradually decentralized with multiple dealers where trust affects the transaction costs. The traditional centralized system is inefficient in the energy sector [13]. It needs greater digital technology, data security, and information trustworthiness [14]. The smart grid has been considered as the "energy internet" for the networking of multi-energy projects [15]. The blockchain technology can provide transparent, decentralized, and secure frameworks for the energy internet [16]. The distributed ledger technology has the ability to provide P2P microgrids with prosumers [17]. The distributed ledgers are grounded on consensus algorithms [18], which can lessen the exchange cost, increase efficiency, enhance trust, and are fast and help P2P transactions on multiple scales [19]. The disruptive technology is the perfect framework for any crowd system type: Tracking, smart contract, proof of ownership (provenance), and identity management (prosumer and machine). The basic blockchain-based network for a crowd system is shown in Figure 1.

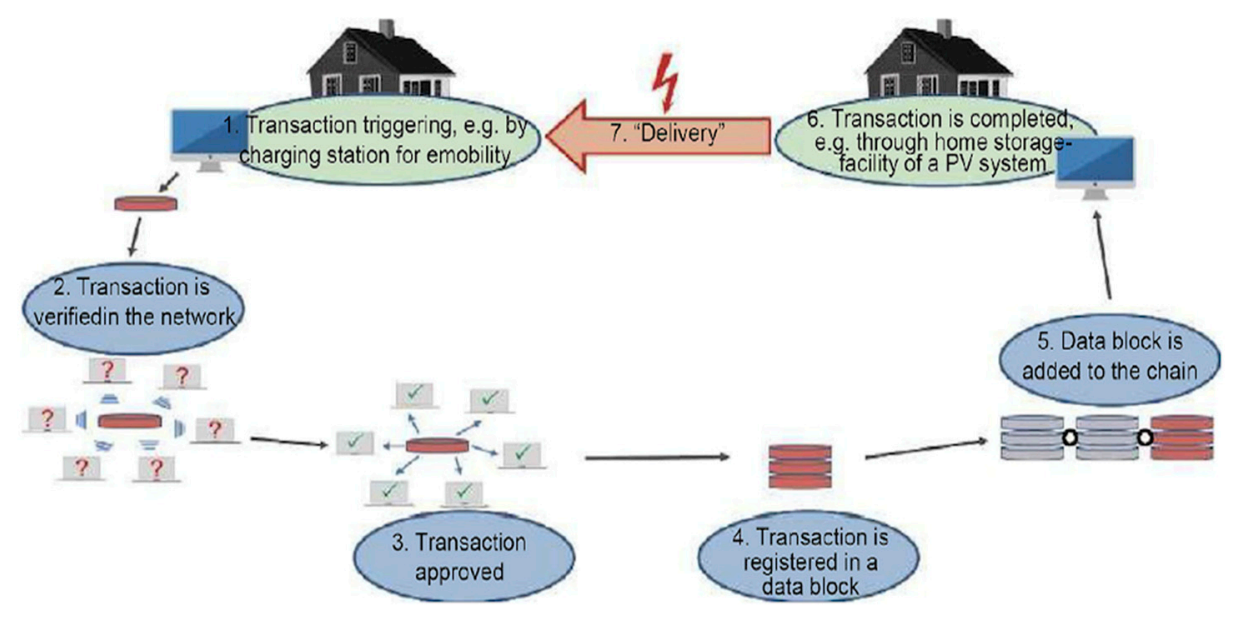

Figure 1. Blockchain-based transaction framework adapted from [20].

The energy market, and the electricity market in particular, is in a transitional stage, based on administrative monitoring and technological developments. The decentralized electricity market is characterized by a great number of dealers with consistent transactions. So, the applicability of distributed ledgers in the energy management determines safety and trust [21]. In a blockchain-based network, all the participants agree on the validity of the data. All members can check and access the data within a specific time, confirming that this ecosystem is transparent. In addition, transparency without a declaration of 
identity is guaranteed. The appraisal is improved more if we consider the brainchild of Nick Szabo, referred to as the smart contract [22]. It allows trusted transactions to take place between disparate anonymous parties without the need for a mechanism of central authority [23]. Consequently, distributed ledgers provide automation for exchange processes, specifically in P2P energy management.

Existing research on the implementation of distributed ledger technology for energy is mostly studied by advanced economies like the US [24,25]. Our study focused on disruptive technology adoption for developing economies. The previous studies mostly focused on the technology organization and environment framework [26]. In this study, we utilized a hypothetical framework based on TAM constructs [27] with cost saving [28] and innovativeness [29], and an in-depth online survey for the measurements. After studying several papers, we analyzed that this is the first paper for the evaluation of disruptive technology adoption in the energy management. The findings indicate that it plays a vital role for both practitioners and policymakers to adopt distributed ledger technology in the energy management. The present study was conducted to answer the subsequent research questions.

RQ1. What are the aspects that drive the attention of the energy sector to implement distributed ledger technology?

RQ2. Among the factors, which has a better impact on the disruptive technology acceptance intention?

The structure of the manuscript is organized as follow: In Section 2, we explain the literature review. Section 3 presents the proposed model. Section 4 explains the methodology. Section 5 clarify the results, and finally the work ends with a discussion and implications.

\section{Literature Review}

\subsection{Distributed Ledger Technology}

A distributed ledger technology is the brainchild of Sakashi Nakamoto [30]. The immense intention of blockchain technology affords amazing features in various sectors of organizations. The blockchain records transactional details between businesses with an unlimited level of security [31]. The distributed ledger technology reduces transaction costs, brings transparency in the supply chain, and increases the traceability in the manufacturing domain for the anti counter measures [32]. The distributed ledgers automatically deliver the required results instantly [33]. The disruptive technology enables the entire world to make contracts embedded in digital codes where all the data is saved authentically without the fear of deletion, revision, and tempering [34]. The distributed ledger technology provides every agreement, every process, and every task with a higher level of validity; it gives digital signatures' verification and the identification of contracts [35]. All the intermediaries in daily life like, including bankers, administrators, lawyers, and stock exchange brokers, might no longer be required [36]. Machines, organizations, individuals, and algorithms will interact with users with little efforts [37]. The entire businesses and economies are revolutionized virtually by the blockchain. In the future, distributive ledger technology will transform businesses and governments in a new way, which concludes the lowest cost solutions [38]. Blockchain technology is the recent tremendous technology that creates innovations and cost reduction in different fields of the economy. Blockchain innovates economic functions, by the peer-to-peer models, boosting small economics and sustainable societies [8]. The blockchain technology provides persistency, automation, auditability, and immutability [39]. These benefits are due to the cryptographic hash nature of the distributed ledger, digital signature of smart contracts, and distributed network of the consensus algorithm [18]. Still, the exact process depends on the consensus mechanism. Three phases of distributed ledger technology applications can be distinguished. The blockchain 1.0 indicates virtualization of digital currencies like bitcoin [30]. Blockchain 2.0 includes smart contracts for the transaction process [40]. The next blockchain 3.0 enables a high level of independency with decentralized autonomous organization based on the savvy contract by predefined complex rules [18]. In addition, in a public/permissionless blockchain, like bitcoin and ethereum, anyone can participate in and access the ledgers [41]. It is mainly based on the proof-of-work algorithm; anyone can add new blocks. While in a private/permissioned blockchain like the hyper 
ledger fabric network, only members can read and write the data. It is mainly based on the proof of authority and proof of stake [26]. Moreover, the consortium is a combination of both permissionless and permissioned blockchains based on predefined rules. Apart from it, tendermint is the most prominently used for allowing a unified swap of tokens among several blockchains [13]. In conclusion, blockchain is a decentralized technology that can lower the cost transaction, provide better security, increase transparency, and improve the traditional system in the organizations [42].

\subsection{Blockchain in Energy Sector}

Blockchain imparts its advantages in various fields like in automotive, finance, manufacturing, internet, and networking. Blockchain technology preserves its tremendous benefits in the energy sector [32]. The world is rapidly shifting toward renewable energy sources due to the furious effects of non-renewable energy on the environment. Several countries aim for a $100 \%$ shift toward renewable energy sources up to 2050, such as Denmark [43]. Recently, some countries (China, Spain, and Germany) have planned to achieve a 70\% implementation of renewable energy sources. The renewable energy transformation is only possible with technological innovations, which are achieved by blockchain technology. The distributed ledger technology provides services direct from the source without the middle man so it reduces a lot of costs and develops trust in the clients [8]. The blockchain implemented in Japan's energy sector is analyzed on the technology, economics, society, environment, and institution. The results emphasized that blockchain will support improvement of the energy sector and the production of zero carbon until 2050 [8]. The research work of [44] focused the blockchain in the energy sector of China. There is concern about the environmental sustainability with renewable energy production. The distributed ledger technology provides a reduction in the cost and ease for the clients for consumption. In addition, the research explored by [7] indicates that blockchain technology became one of the top 10 successful technologies in the year 2018. It works in many areas as a promising technology, for energy technological development, and is featured for future technological advancements in the energy sector. The specific energy applications of blockchain include P2P trading, energy storage arrangements, and manageable loads. The authors of [45] studied the distributed ledger technology applications for the energy marketplace setting, containing two manufacturers and one customer. The author discussed the viability of disruptive technology to Industry 4.0 and concluded that distributed ledgers play a pivotal role in the energy market. The authors of $[45,46]$ proposed a blockchain base-distributed demand-side management model that could match the demand for energy production. The authors of [47] investigated the smart grid concept with blockchain technology from the perspective of energy production. The smart grid replaces the conventional method of energy production. The research concluded that the blockchain provides new and secure ways of energy production. The authors of [13] studied 140 blockchain projects and its possible effects on energy companies. The findings indicate that disruptive technology greatly lessens the exchange cost like processing data and confirmation, which led the marketplace to embrace minor distributed generators. The authors of [48] proposed a distributed ledgers-based model for development of the distributed microgrid energy trade algorithms. The authors of [49] conceived an energy blockchain-based scheme for safe electric vehicle-charging services in the smart city. The authors of [50] proposed a decentralized market network from which prosumers and consumers could use the blockchain to exchange local electricity. The author analyzed their decentralized market based on 100 households, indicating that this could lessen the future cost. In conclusion, the disruptive technology is useful in the energy transaction, supply chain, and energy internet. The distributed ledgers-based energy framework could bring efficiency in the traditional energy system, and consequently lower the energy cost for end consumers.

\subsection{Technology Adoption Model}

Technological development and advancements always impart a vital position in the financial growth of a country. Various researches have focused on the technology adoption model like [51], who worked on the adoption of consumers towards renewable energy consumption with a comparison of the perceived attributes and the attitude intentions were determined. The case of solar Photovoltaic 
cell installation in the USA [52], and efficiency programs for the adoption of new and used energy technology using the spatial energy growth model [53]. Technological development in the energy sectors can enhance the sustainable environment of the country. The above-mentioned technology projects are for the betterment of society and consumers' well-being, but it is subject to the technology adoption.

\subsection{TAM}

The technological acceptance model is offered by [27], and indicates a subdivision of the theory of reasoned action (TRA) especially designed for user adoption behavior. Accordingly, [27] implemented the TAM in the implementation of computer-based information systems in organizations to get an enhanced organization performance. To get increased user acceptance, it is necessary to explain why people should accept the work on computer information systems [54]. TAM emphasized the determinants of computer acceptance working, which is it provides better user behavior, end-user computer technologies, and a broad range of performance [55]. TAM is not only helpful for the prediction but also for aiding both practitioners and researchers to identify it pursues some appropriate steps [56]. The goal of the TAM is based on two main concepts: Perceived usefulness (PU) and perceived ease of use (PEOU). It is one of the prominent models that predicts user behavioral intention to accept a new technology $[54,57]$ and is the leading model [58] in the literature. The recent literature on TAM is presented in Table 1.

Table 1. Technology Acceptance Model literature.

\begin{tabular}{|c|c|c|}
\hline Authors & Study Objectives & Results \\
\hline [59] & $\begin{array}{l}\text { Using TAM four variables in the energy } \\
\text { sector (Perceived behavior, moral } \\
\text { norms, awareness, and social norms). }\end{array}$ & $\begin{array}{l}\text { The paper concluded TAM in the renewable energy sector in Iran. } \\
\text { The findings confirm a significant relationship among the variables of } \\
\text { intentions and a negative relationship with intentions in terms of } \\
\text { social norms. }\end{array}$ \\
\hline [60] & $\begin{array}{l}\text { The paper is about the implementation } \\
\text { of Green IT using the extended TAM. } \\
\text { The study predicts environment IT is an } \\
\text { emerging trend. }\end{array}$ & $\begin{array}{l}\text { The study determined the TAM for Green IT by using constructs } \\
\text { (injunctive, descriptive, and personnel norms). The results describe } \\
\text { that environmental beliefs, descriptive, personal norms, and } \\
\text { perceived usefulness directly impact the intentions towards green IT. } \\
\text { Moreover, environmental beliefs and government policies have } \\
\text { significant effects on normative variables. }\end{array}$ \\
\hline [61] & $\begin{array}{l}\text { The study focus on importance of } \\
\text { psychological ownership of user } \\
\text { attitudes performed in the organization. }\end{array}$ & $\begin{array}{l}\text { The research is connected with the TAM of antecedents and results } \\
\text { with psychological ownership. TAM has a significant relationship in } \\
\text { long term customer loyalty and customer engagement in media use. }\end{array}$ \\
\hline [62] & $\begin{array}{l}\text { The work is about perceived usefulness, } \\
\text { how the users get to use the blockchain } \\
\text { technology in the digital world } \\
\text { transactions. The paper specifically } \\
\text { focused on Twitter insights of users. }\end{array}$ & $\begin{array}{l}\text { Blockchain technology is the modern emergence in the digital world. } \\
\text { The paper explores the individual acceptance toward the disruptive } \\
\text { technology models and exchanges. The research concluded that users } \\
\text { are inclined towards security, ease of use, traceability, verifications, } \\
\text { and digital transactions. The paper explains the managerial } \\
\text { implications with the future of blockchain technology. }\end{array}$ \\
\hline [63] & The adoption Cycle of Cryptocurrency. & $\begin{array}{l}\text { The research discussed the TAM from the perspective of Blockchain } \\
\text { technology. The study explains the consumer's acceptance behavior } \\
\text { by using digital currencies. }\end{array}$ \\
\hline [64] & $\begin{array}{l}\text { Blockchain technology as a } \\
\text { decentralized Business. A sharing } \\
\text { economy perspective with technology } \\
\text { adoption Model (TAM) }\end{array}$ & $\begin{array}{l}\text { The work focused on the blockchain technology adoption in the } \\
\text { business and economy. The work explains the business transactions } \\
\text { which are decentralized and more secured using BT. The paper } \\
\text { elaborates on the ease of use and technology adoption models using } \\
\text { Blockchain technology. }\end{array}$ \\
\hline [65] & $\begin{array}{l}\text { Blockchain Technology in terms of } \\
\text { Business Sustainability and Adoption } \\
\text { behaviors of users in SMEs, Hospitality, } \\
\text { and Tourism sector. }\end{array}$ & $\begin{array}{l}\text { The paper determined the implementation of the Cryptocurrency in } \\
\text { Small and Medium-sized firms like the Hospitality sector, Small } \\
\text { business, and Tourism under the Technology Adoption Model for the } \\
\text { business transaction. The results declared that managers of the } \\
\text { organizations play a key role to implement Blockchain Technology. } \\
\text { Perceived usefulness works as a mediating factor among } \\
\text { strategic orientation. }\end{array}$ \\
\hline [66] & $\begin{array}{l}\text { Adoption of blockchain technology for } \\
\text { financial development. }\end{array}$ & $\begin{array}{l}\text { The study focused on the expansion of the supply chain structure of } \\
\text { India to the rural areas. Authors analyzed implementation of } \\
\text { Blockchain technology in remote areas to get economic development. } \\
\text { BT connects the rural areas with the global business. It is concluded } \\
\text { that Technology Adoption is necessary for economic growth. }\end{array}$ \\
\hline
\end{tabular}




\section{Proposed Model}

In Section 2, we discussed several research papers regarding technology adoption models. Our study assimilates TAM constructs with cost saving and innovativeness for the subsequent goals. First, the customer intention to implement innovative technology could be discussed by [67]. Second, TAM is banded on system-specific perception and cost saving is money saved by using an advance technology [68]. Third, innovativeness is considered as the sparks of the technology [69]. Therefore, the present study expands the TAM constructs with the cost saving construct proposed by [28] and the innovativeness construct proposed by [29] to comprehend the acceptance of blockchain in the the energy management of developing countries context. How the behavioral intention attitude is established and what position the perceived ease of use and perceived usefulness are playing will be evaluated by using the technology adoption model. The proposed model is shown in Figure 2.



1.Technology Acceptance Model(TAM) includes Perceived usefulness, Perceived ease of use and attitude
2.Cost saving construct proposed by Globerson \& Maggard (1991)

3. Innovativeness construct from Technology readiness Index (TRI)

Conceptual Model

Figure 2. Conceptual model.

\subsection{Hypothesis Development}

The TAM construct perceived usefulness is the customer's personal belief that with the use of some advanced methods, his or her job performance will increase in the organization. While, perceived ease of use emphasizes that the adopted technology or system provides comfort of practice. Moreover, TAM plays a vital role to provide effective ways to influence external factors on internal beliefs, behavioral intention (BI), and attitude (ATT). Attitude is a user's favorable or unfavorable assessment of the conduct being referred to [70]. Attitude with regard to user acceptance of IT is characterized as a person's general productive response (loving, delight, happiness, and joy) to utilize technology [27].

The results from the past research proposed that the perceived ease of use has a significant impact on perceived usefulness [67,71,72]. Moreover, perceived ease of use has positive impact on attitude [73-75]. Perceived usefulness positively impacts attitude [76,77]. Attitude has a positive impact on behavioral intention [27,78-81]. Perceived usefulness has a positive effect on the user's intention [82-84]. Similarly, this study also expects that TAM constructs along with cost saving and innovativeness will also show a noteworthy effect on the user's intention to adopt blockchain in the energy management. So, we postulate the following hypotheses: 
Hypothesis 1. Perceived ease of use has a positive effect on the perceived usefulness of blockchain technology

Hypothesis 2. Perceived ease of use has a positive effect on the attitude towards blockchain technology

Hypothesis 3. Perceived usefulness has a positive effect on the attitude towards blockchain technology

Hypothesis 4. Attitude has a positive effect on the behavioral intention to use blockchain technology

Hypothesis 5. Perceived usefulness has a positive effect on the behavioral intention to use blockchain technology.

\subsubsection{Cost Saving}

It refers to the time and money saved by using an advanced technology [68]. The perceived cost savings are considered to be "the extent by which user thinks about use of a specific framework will save money spent on service operation" [85]. Moreover, [86] listed the saved money factor as one of the sub-categories that pushes clients to select self-services. The authors of [87] discovered that price and cost savings were one of the major benefits that favored self-service. The authors of [88] identified that the higher the effort taken by the user to participate in self-service, the lesser the amount the user usually expects to pay for that service. The previous findings confirm that cost saving has a positive effect on Perceived ease of use [89-91]. Moreover, cost saving has a positive effect on perceived usefulness [92-94]. Accordingly:

Hypothesis 6. Cost saving has a positive effect on the perceived usefulness of blockchain technology

Hypothesis 7. Cost saving has a positive effect on the perceived ease of use of blockchain technology

\subsubsection{Innovativeness}

The innovativeness construct is derived from the technology readiness index [29]. It is a desire to be a technology leader and visionary [95]. Positive thinking can be used as a guide to a positive outlook for creativity, and it fills in as a confidence that it can create efficiency and adoptability. Innovativeness is measured as the incentives of the technology [69]. The previous findings indicate that innovativeness has a significant effect on perceived usefulness [96,97]. Moreover, innovativeness has a positive impact on the perceived ease of use [98-100]. Thus:

Hypothesis 8. Innovativeness has a positive effect on the perceived usefulness of blockchain technology

Hypothesis 9. Innovativeness has a positive effect on the perceived ease of use of blockchain technology

\section{Research Methodology}

\subsection{Data Collection}

An online survey approach was used for the current analysis by using the Google Form service to investigate the connection amongst the conceptual model constructs. Therefore, online data, using the official English language, were developed to get the feedback from experts working in the energy sector of a developing country. To assess the feedback, a 5-point Likert scale closed-ended questionnaire and pilot testing process were used [101,102]. For the four months (January 2020-April 2020), an online survey was conducted for the four major electric supply companies of a developing economic in Asia, namely IESO, FESCO, PESCO, and LESCO. Due to the pandemic situation, in four months, 178 complete questionnaires were received and used for the measurement model. The final sample 
size consisted of 178 experts representing four major supply companies. The sample size satisfied the standard requirement of 5 observations per parameter [103]. In the current research, we selected 19 factors with a minimum requirement of 165 respondents. Moreover, [104] suggested a small sample size is enough for an energy study. So, the sample size of 178 experts was acceptable for the structural model analysis. The top companies for the study were IESCO $(30.33 \%)$ and FESCO $(24.71 \%)$. The designation of a deputy secretary represents the highest percentage (38.20\%). More data were collected from experts, representing $16.29 \%$. The majority of employees in the energy sector have more than 10 years of experience, representing $29.21 \%$. The details of the respondents' demographic profile are presented in the Table 2.

Table 2. Respondents' profile.

\begin{tabular}{cccc}
\hline & & Frequency & Percentage \\
\hline Designation & Chairman & 08 & $4.49 \%$ \\
& Director & 16 & $8.98 \%$ \\
& Executive Director & 32 & $17.97 \%$ \\
Secretary & 34 & $19.10 \%$ \\
Experience & Deputy Secretary & 68 & $38.20 \%$ \\
& Research and Development Experts & 20 & $11.23 \%$ \\
& $\leq 5$ years & 33 & $18.53 \%$ \\
Areas & >10 years & 45 & $25.28 \%$ \\
& $>10$ years & 52 & $29.21 \%$ \\
& $>15$ years & 48 & $26.96 \%$ \\
& Islamabad division & 28 & $15.73 \%$ \\
& Rawalpindi division & 24 & $13.48 \%$ \\
& Sargodha & 22 & $12.35 \%$ \\
& Mianwali & 26 & $14.60 \%$ \\
& Khyber circle & 17 & $9.55 \%$ \\
& Peshawar circle & 14 & $7.86 \%$ \\
& Okara & 18 & $10.11 \%$ \\
& Kasur & 29 & $16.29 \%$ \\
& IESCO & 54 & $30.33 \%$ \\
& FESCO & 44 & $24.71 \%$ \\
& PESCO & 42 & $23.59 \%$ \\
& LESCO & 38 & $21.34 \%$ \\
\hline
\end{tabular}

$N=178$; Emails of the professionals are not shown by the request of them.

\subsection{Structural Equation Modeling}

For the current analysis, partial least square structure equation modeling was used $[88,105]$. The first-generation techniques were not used because of their limited capability with regards to casual and complex modeling [106]. Among the second-generation analysis techniques, PLS-SEM is widely adopted and accepted $[107,108]$. The SmartPLS is more specifically used in terms of studying technology adoption models. The details of the measurement items are presented in Table 3. 
Table 3. Construct measurement.

\begin{tabular}{|c|c|c|c|}
\hline Construct & Code & Question & Adapted From \\
\hline \multirow[t]{4}{*}{ Perceived Ease of use } & PEOU1 & $\begin{array}{l}\text { Blockchain technology is compatible for energy } \\
\text { management }\end{array}$ & \multirow[t]{4}{*}[27,63,73,109,110]{} \\
\hline & PEOU2 & You think blockchain technology is faultless & \\
\hline & PEOU3 & $\begin{array}{l}\text { It is easy to do multitask through blockchain } \\
\text { quickly }\end{array}$ & \\
\hline & PEOU4 & $\begin{array}{l}\text { Blockchain is easy to use than traditional Energy } \\
\text { management system }\end{array}$ & \\
\hline \multirow[t]{4}{*}{ Perceived Usefulness } & PU1 & Blockchain can help firms for fast transactions & \multirow[t]{4}{*}[27,111]{} \\
\hline & PU2 & Blockchain can bring transparency in firms & \\
\hline & PU3 & Blockchain can help in anti counter measures & \\
\hline & PU4 & $\begin{array}{l}\text { Blockchain technology can help you to reach } \\
\text { stock in a real time }\end{array}$ & \\
\hline \multirow[t]{2}{*}{ Attitude } & ATT1 & $\begin{array}{l}\text { In your opinion, blockchain is necessary for } \\
\text { Energy sector }\end{array}$ & \multirow[t]{2}{*}[27,84,112]{} \\
\hline & ATT2 & $\begin{array}{l}\text { You think, blockchain will improve the } \\
\text { traditional energy management system }\end{array}$ & \\
\hline \multirow[t]{4}{*}{ Cost Saving } & CS1 & $\begin{array}{l}\text { Distributed ledgers will reduce transaction cost } \\
\text { in the firms }\end{array}$ & \multirow[t]{4}{*}[28,85,113]{} \\
\hline & CS2 & Distributed ledgers are cost-effective & \\
\hline & CS3 & $\begin{array}{l}\text { Distributed ledgers are compatible for improving } \\
\text { supply chain efficiencies and cost saving }\end{array}$ & \\
\hline & CS4 & $\begin{array}{l}\text { Distributed ledgers are compatible with most } \\
\text { aspects of Energy Management firms }\end{array}$ & \\
\hline \multirow[t]{2}{*}{ Innovativeness } & INN1 & $\begin{array}{l}\text { Other people give you suggestion to use } \\
\text { blockchain technology for access at your firm }\end{array}$ & \multirow[t]{2}{*}[29,63]{} \\
\hline & INN2 & $\begin{array}{l}\text { You would usually use blockchain to access your } \\
\text { firm database without any help }\end{array}$ & \\
\hline \multirow[t]{3}{*}{ Intention to Use } & BI2 & Firms will use distributed ledgers very well & \multirow[t]{3}{*}[68,77,114]{} \\
\hline & BI3 & $\begin{array}{l}\text { It is expected that Energy firms will take } \\
\text { advantages from the blockchain application in } \\
\text { the manufacturing and service operations. }\end{array}$ & \\
\hline & BI34 & $\begin{array}{l}\text { By developing blockchain technology, Energy } \\
\text { sector would increase resource usage and } \\
\text { provide better services. }\end{array}$ & \\
\hline
\end{tabular}

\subsection{Common Method Bias Issues}

For sample characteristics, a Kolmogorov and Smirnov test $(P>0.05)$ was applied to examine sample distribution of the initial and later non-response bias respondents $[115,116]$. As indicated by [117], the mean response to all the constructs shown in the proposed model provided by 46 respondents over the last six weeks was matched by the random sample of 132 respondents of the early ten-week return to determine whether any significant differences occured. The study was appropriate because the respondents who submitted their questionnaires late were approximately identical to the non-respondents [118]. The non-response bias findings are presented in Table 4 . Moreover, the use of a single instrument to assess exogenous and endogenous structures usually raises questions about common method bias issues [119]. Therefore, both methodological and statistical methods were used to prevent the common method bias problems. The statistical solution was implemented by the Harmon's test. Consequently, the findings showed the data variation was recorded by the first factor by $38.274 \%$. Since the outcome is below $50 \%$, it could be assumed that there was no Commom method bias problem [120]. Moreover, the variance inflation factor (VIF) was tested before checking the structural model to detect the existence of the high correlated construct. Consequently, the findings showed that the high VIF value among the construct was 3.261 below the standard cut-off threshold of 5 [121]. The results indicate that this research does not pose a significant multicollinearity problem and is suitable for the measurement model. For Variance Inflation Factor, see Table 5. 
Table 4. Non-response bias.

\begin{tabular}{ccccc}
\hline Construct & $\mathbf{N}$ & S.D & Mean & Sig. Value \\
\hline \multirow{2}{*}{ ATT } & ER $=132$ & 0.743 & 3.17 & 0.92 \\
& LR $=46$ & 0.756 & 3.32 & \\
BI & ER $=132$ & 0.643 & 3.65 & 0.74 \\
& LR $=46$ & 0.723 & 3.74 & \\
CS & ER $=132$ & 0.856 & 3.54 & 0.85 \\
& LR $=46$ & 0.863 & 3.17 & \\
INN & ER $=132$ & 0.927 & 3.44 & 0.92 \\
PEOU & LR $=46$ & 0.914 & 3.54 & \\
& ER $=132$ & 0.896 & 3.63 & 1 \\
PU & LR $=46$ & 0.732 & 3.28 & \\
& ER $=132$ & 0.764 & 3.72 & 1 \\
& LR $=46$ & 0.756 & 3.15 &
\end{tabular}

ATT = Attitude, $\mathrm{PU}=$ Perceived usefulness, $\mathrm{BI}=$ Behavioral intention, $\mathrm{CS}=$ Cost saving, INN $=$ Innovativeness, $\mathrm{PEOU}=$ Perceived ease of use, ER $=$ Early respondent, $\mathrm{LR}=$ Late respondent, $\mathrm{S} . \mathrm{D}=$ Standard deviation.

Table 5. Variance Inflation Factor checks.

\begin{tabular}{|c|c|c|c|c|c|c|c|c|}
\hline Inner VIF & Values & & & & & & Outer VIF & Outer Values \\
\hline & & & & & & & ATT1 & 1.615 \\
\hline & ATT & BI & CS & INN & PEOU & PU & ATT2 & 1.615 \\
\hline ATT & & 2.644 & & & & & BI2 & 1.976 \\
\hline BI & & & & & & & $\mathrm{BI} 3$ & 1.469 \\
\hline CS & & & & & 1.276 & 1.812 & BI34 & 1.660 \\
\hline INN & & & & & 1.276 & 1.321 & CS1 & 1.661 \\
\hline PEOU & 3.261 & & & & & 1.723 & CS2 & 1.552 \\
\hline PU & 3.261 & 2.644 & & & & & CS3 & 1.871 \\
\hline & & & & & & & CS4 & 1.519 \\
\hline & & & & & & & INN1 & 1.692 \\
\hline & & & & & & & INN2 & 1.692 \\
\hline & & & & & & & PEOU1 & 1.953 \\
\hline & & & & & & & PEOU2 & 1.975 \\
\hline & & & & & & & PEOU3 & 2.332 \\
\hline & & & & & & & PEOU4 & 2.048 \\
\hline & & & & & & & PU1 & 1.966 \\
\hline & & & & & & & PU2 & 2.143 \\
\hline & & & & & & & PU3 & 2.427 \\
\hline & & & & & & & PU4 & 2.102 \\
\hline
\end{tabular}

ATT $=$ Attitude, PU $=$ Perceived usefulness, BI = Behavioral intention, $C S=$ Cost saving, INN = Innovativeness, PEOU $=$ Perceived ease of use.

\section{Results}

The conceptual model was tested by a two-step process. First, we tested the reliability and validity checks. In step two, we analyzed the structural equation model.

\subsection{Measurement Model}

For the measurement model, validity is the degree to which information gathering approaches extend whatever they were intended to measure. Therefore, for the current proposed model, the subsequent analyses were implemented. When the hypothetical constructs established for the model are highly correlated with the elements used for measuring it, we have to check for convergent validity. In other words, the ratio of the variation common through the measures of a particular construct must be high. In the proposed model, we tested for the six constructs. As per the guidelines, we performed the following validity checks. 
- First, we checked the factor loadings. Consequently, the construct was above the standard of 0.5 as suggested by [122]. The factor loadings are presented in Table 6. The measurement model is shown in Figure 3.

Table 6. Outer loadings.

\begin{tabular}{ccccccc}
\hline & ATT & BI & CS & INN & PEOU & PU \\
\hline ATT1 & 0.896 & & & & & \\
ATT2 & 0.903 & & & & & \\
BI2 & & 0.876 & & & & \\
BI3 & & 0.761 & & & & \\
BI34 & & 0.850 & & & & \\
CS1 & & & 0.796 & & & \\
CS2 & & & 0.751 & & & \\
CS3 & & & 0.843 & & & \\
CS4 & & & 0.774 & & & \\
INN1 & & & & 0.927 & & \\
INN2 & & & & & 0.881 & \\
PEOU1 & & & & 0.818 & \\
PEOU2 & & & & 0.831 & \\
PEOU3 & & & & & 0.818 \\
PEOU4 & & & & & 0.875 \\
PU1 & & & & & & \\
PU2 & & & & & & \\
PU3 & & & & & & \\
PU4 & & & & & & \\
\hline
\end{tabular}

Note. ATT $=$ Attitude, $\mathrm{PU}=$ Perceived usefulness, $\mathrm{BI}=$ Behavioral intention, $\mathrm{CS}=$ Cost saving, $\mathrm{INN}=$ Innovativeness, PEOU $=$ Perceived ease of use .

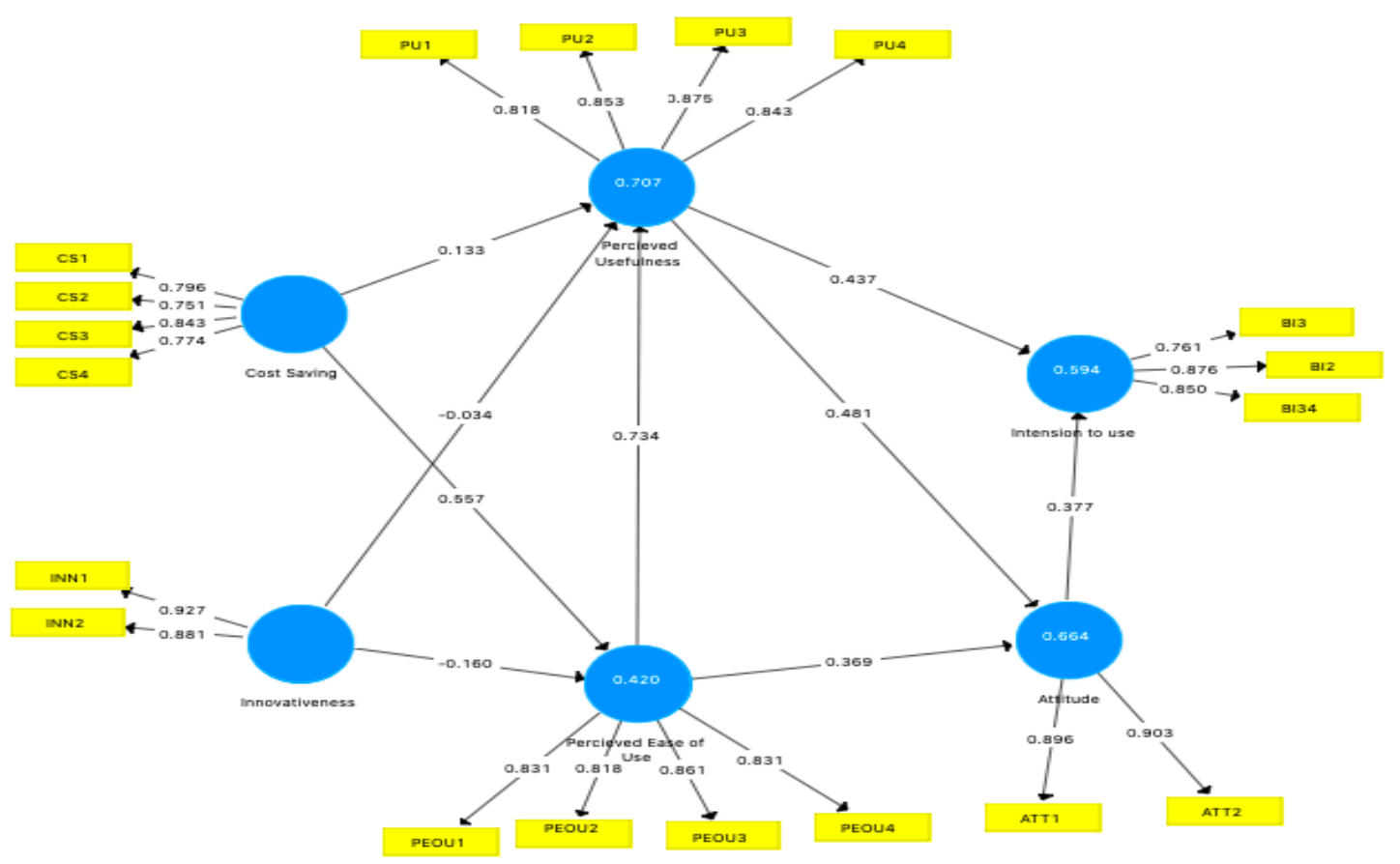

Figure 3. Measurement model.

\subsubsection{Construct Reliability}

After checking the factor loading, we tested the composite reliability as suggested by [122] and the average variance extracted proposed by [123]. Based on the findings, it is indicated that all the values were found above the standard value ( 0.7 for CR and 0.5 for AVE) as presented in Table 7. 
Table 7. Construct reliability.

\begin{tabular}{cccc}
\hline & CA & CR & AVE \\
\hline ATT & 0.763 & 0.894 & 0.809 \\
BI & 0.775 & 0.869 & 0.690 \\
CS & 0.801 & 0.870 & 0.627 \\
INN & 0.780 & 0.900 & 0.818 \\
PEOU & 0.855 & 0.902 & 0.698 \\
PU & 0.869 & 0.911 & 0.718 \\
\hline
\end{tabular}

Note. $\mathrm{CA}=$ Cronbach's Alpha, $\mathrm{CR}=$ Composite Reliability, AVE = Average variance extracted.

\subsubsection{Discriminant Validity}

After checking the CR and AVE, we tested the discriminant validity (DV) as recommended by [123]. The DV shows the square root of AVE, with each hidden variable in the proposed model. Consequently, constructs would show high variance with their measures than with other constructs. The DV for each construct is very well established and is presented in Table 8. In addition, the HTMT ratios for checking the normality of the DV are presented in Table 9.

Table 8. Discriminant validity.

\begin{tabular}{ccccccc}
\hline & ATT & BI & CS & INN & PEOU & PU \\
\hline ATT & 0.899 & & & & & \\
BI & 0.722 & 0.831 & & & & \\
CS & 0.709 & 0.655 & 0.792 & & & \\
INN & -0.456 & -0.433 & -0.465 & 0.904 & & \\
PEOU & 0.770 & 0.744 & 0.632 & -0.420 & 0.835 & \\
PU & 0.789 & 0.735 & 0.613 & -0.404 & 0.833 & 0.848 \\
\hline
\end{tabular}

Table 9. Heterotrait-Monotrait Ratios.

\begin{tabular}{ccccccc}
\hline & ATT & BI & CS & INN & PEOU & PU \\
\hline ATT & & & & & & \\
BI & 0.826 & & & & & \\
CS & 0.802 & 0.820 & & & & \\
INN & 0.582 & 0.548 & 0.571 & & & \\
PEOU & 0.852 & 0.809 & 0.761 & 0.505 & & \\
PU & 0.867 & 0.889 & 0.731 & 0.486 & 0.864 & \\
\hline
\end{tabular}

Note. HTMT $=$ Heterotrait-Monotrait Ratios.

\subsection{Structural Model}

In the second phase, we applied the bootstrapping process for testing the normality of the data. In this process, a large number of subsamples (5000) were taken from the original sample to check errors. The result provides the T-values for the significance of the measurement model. So, the bootstrapping process for the structural model is shown in Figure 4. 


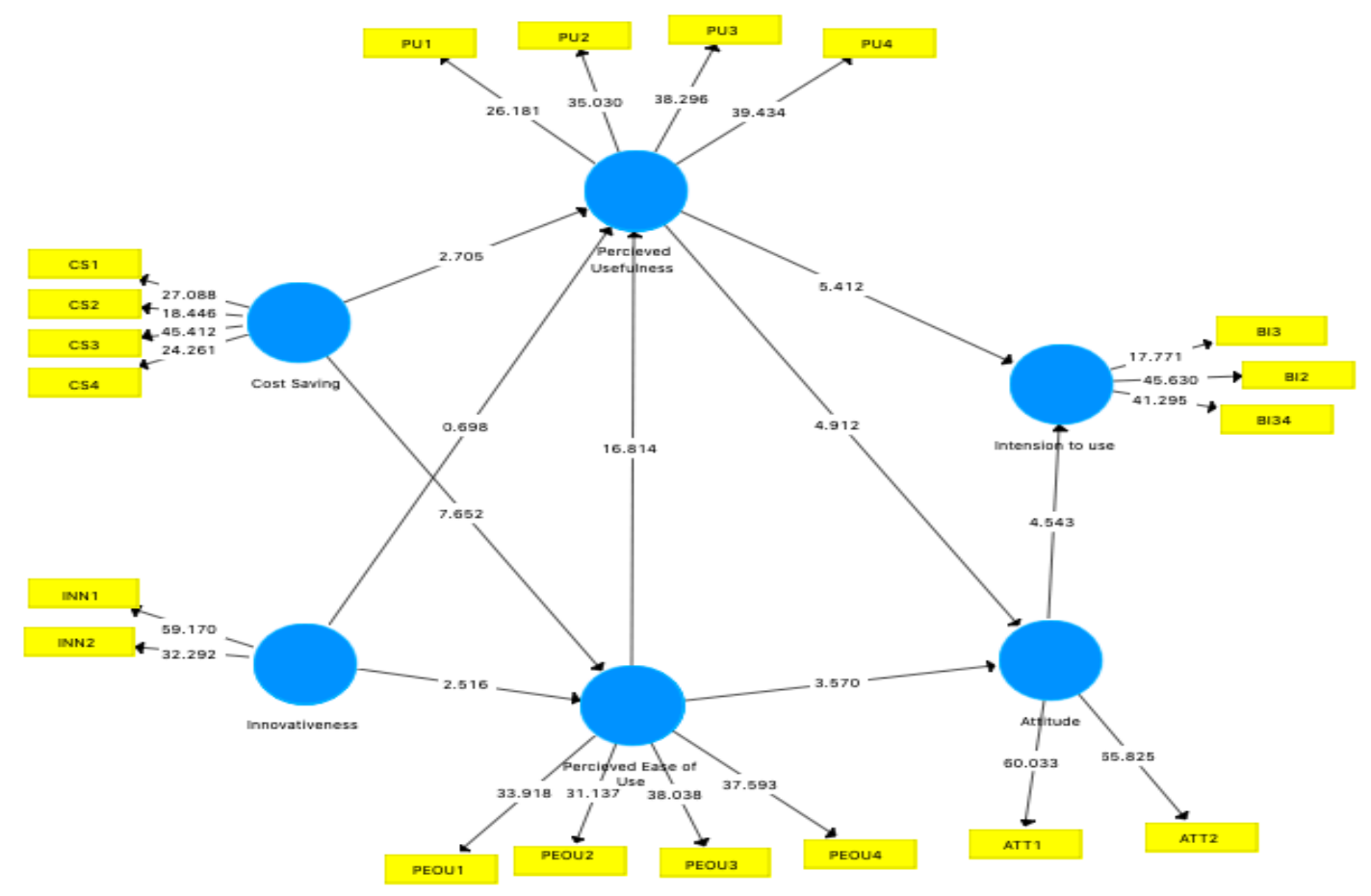

Figure 4. Structural model.

\subsubsection{Goodness of Model Fit}

This study's goodness of model fit was obtained by including the exclusion process for items. Five measures were applied, namely SRMR, d ULS, d G, Chi square, and NFI. Accordingly, the model tested meets all of them (especially SmartPLS SRMR and NFI) because according to [124], the standard value for SRMR is less than 0.08 and higher than 0.9 for NFI. Hence, the model fit is presented in Table 10. In addition, the path coefficients are shown in Table 11.

Table 10. Model fit.

\begin{tabular}{cccccc}
\hline & $\mathbf{R}^{\mathbf{2}}$ & $\mathbf{R}^{\mathbf{2}}$ Adjusted & & $\mathbf{S M}$ & EM \\
\hline ATT & 0.664 & 0.660 & SRMR & 0.061 & 0.077 \\
BI & 0.594 & 0.589 & d_ULS & 0.708 & 1.135 \\
PEOU & 0.420 & 0.413 & d_G & 0.456 & 0.528 \\
PU & 0.707 & 0.702 & Chi-Square & 478.392 & 523.820 \\
& & & NFI & 0.979 & 0.959 \\
\hline
\end{tabular}

Note. $\mathrm{SM}=$ Saturated Model, EM = Estimated Model.

Table 11. Hypothesis test results.

\begin{tabular}{|c|c|c|c|c|c|c|c|}
\hline & & O & $\mathbf{M}$ & SD & T Values & $P$ Values & Decision \\
\hline H1 & PEOU -> PU & 0.734 & 0.731 & 0.041 & 17.735 & 0.000 & Accepted \\
\hline $\mathrm{H} 2$ & PEOU $->$ ATT & 0.369 & 0.364 & 0.098 & 3.755 & 0.000 & Accepted \\
\hline H3 & PU -> ATT & 0.481 & 0.489 & 0.093 & 5.154 & 0.000 & Accepted \\
\hline $\mathrm{H} 4$ & ATT $->$ BI & 0.377 & 0.367 & 0.091 & 4.160 & 0.000 & Accepted \\
\hline H5 & PU $->$ BI & 0.437 & 0.450 & 0.088 & 4.979 & 0.000 & Accepted \\
\hline H6 & $C S->$ PU & 0.133 & 0.137 & 0.047 & 2.822 & 0.005 & Accepted \\
\hline $\mathrm{H} 7$ & CS -> PEOU & 0.557 & 0.559 & 0.076 & 7.363 & 0.000 & Accepted \\
\hline $\mathrm{H} 8$ & INN -> PU & -0.034 & -0.036 & 0.049 & 0.682 & 0.496 & Rejected \\
\hline $\mathrm{H} 9$ & INN -> PEOU & -0.160 & -0.164 & 0.066 & 2.409 & 0.016 & Accepted \\
\hline
\end{tabular}

Note. $\mathrm{O}=$ Original Sample Beta, $\mathrm{M}=$ Sample Mean, $\mathrm{SD}=$ Standard Deviation. 


\subsubsection{Structural Model Assessment}

As per the guidelines, ${ }^{*} p<0.05,{ }^{* *} p<0.01,{ }^{* * *} p<0.001$. The relation between PEOU and PU had the following outcome $(\beta=0.734, \mathrm{~T}=17.735, P=0.000)$, so hypothesis 1 is accepted. Similarly, the relationship between PEOU and ATT got the following value $(\beta=0.369, \mathrm{~T}=3.755, P=0.000)$, therefore hypothesis 2 is accepted. The relationship between PU and ATT got the following result ( $\beta=0.481, \mathrm{~T}=5.154, P=0.000)$, so hypothesis 3 is accepted. Then, the relationship between ATT and $\mathrm{BI}$ got the following outcome $(\beta=0.377, \mathrm{~T}=4.160, P=0.000)$, therefore hypothesis 4 is accepted. The relationship between PU and BI got the following ( $\beta=0.437, \mathrm{~T}=4.979, P=0.000)$, so hypothesis 5 is accepted. The relationship between CS and PU got the following $(\beta=0.133, \mathrm{~T}=2.822, P=0.005)$, therefore hypothesis 6 is supported. The relationship between CS and PEOU got the following result ( $\beta=0.557, \mathrm{~T}=7.363, P=0.000$ ), so hypothesis 7 is accepted. However, the relationship between INN and PU got the following result ( $\beta=-0.034, T=0.682, P=0.496)$, so hypothesis 8 is rejected. Finally, the relationship between INN and PEOU got the following outcome $(\beta=-0.160, \mathrm{~T}=2.409, P=0.016)$, so hypothesis 9 is accepted. It is indicated from Table 11 that all the hypotheses showed a significant relationship except innovativeness on perceived usefulness.

\section{Discussion}

\subsection{Major Findings}

The current study confirms that the perceived ease of use shows a positive effect on the perceived usefulness and is supported by previous studies of [84,125-127]. Moreover, the perceived ease of use shows a positive and significant impact on attitude and is supported by the other studies of [128-130]. The perceived usefulness shows a positive effect on attitude and is supported by the previous studies of [131-133]. Attitude confirms a positive effect on the behavioral intention to use blockchain technology and is supported by the other studies of $[84,129,134]$. In addition, the perceived usefulness shows a significant effect on the behavioral intention to use distributed leger technology for the energy management and is supported by the previous studies of $[84,135,136]$. The findings indicate that the adoption of distributed ledger technology will improve the technical features (privacy and speediness) for distributed energy resources' businesses to increased flexibility [137].

It was interesting to find that cost saving shows a positive effect on the perceived ease of use and is supported by other studies [89,92-94]. Moreover, cost saving also shows a positive effect on the perceived usefulness and is supported by previous studies [89-91]. The findings indicate that distributed ledger technology could lessen the transaction cost, although delivering clear information for entry to many groups, and counting groups that verify monitoring compliance. Thus, distributed leger technology could eliminate the central authority and probably trade volumes, and aid in this manner to minor-scale customers to participate in energy markets [44]. The results also indicate that innovativeness shows a significant effect on the perceived ease of use while an insignificant effect on the perceived usefulness. In such context, it may be due to the lack of awareness about blockchain technology in developing countries. Still, it is in the beginning phase in developing nations. The findings suggest for the firms that their advertising agencies should not only focus on developing the awareness about distributed ledger technology but also buy the applications of blockchain for its actual use in the organizations [138].

\subsection{Theoretical Implications}

The current study responded to a request by [139], who emphasized that there is a vital need to enhance the contemporary state of the blockchain topic. Certainly, until now, the literature on distributed ledger technology is commonly a review type like $[8,13,140,141]$. In this way, through the integration of TAM constructs with cost saving and innovativeness by empirical evidence from the energy sector, the current study complements the limited literature on the distributed ledger acknowledgement model for technology innovation by analyzing an empirical model. So, our study 
plays a key role in the field of information technology implementation for energy management, given by the anticipated impact of blockchain technology. The present study is one of the initial studies using SmartPLS, findings from a statistically confirmed model, exposing that TAM constructs with cost saving can serve as a base for blockchain acceptance in energy management. Our projected model suggested related information visions that can help experts as well as scholars recognize and progress their work if they incorporate disruptive technology in their energy management.

\subsection{Practical Implication}

Based on the findings, the current study indicates that the proposed model holds a strong explanatory power $\left(R^{2}=0.594\right.$ and $R^{2}$ adjusted $\left.=0.589\right)$, explaining $59.4 \%$ of the variance of the behavioral intention. Moreover, attitude exhibits a variance of $\left(R^{2}=0.5664\right.$ and $R^{2}$ adjusted $=$ 0.660). Similarly, the perceived ease of use shows a variance $\left(R^{2}=0.420\right.$ and $R^{2}$ adjusted $\left.=0.413\right)$. Hence, the perceived usefulness exhibits a strong variance $\left(R^{2}=0.707\right.$ and $R^{2}$ adjusted $\left.=0.702\right)$. Developing countries have begun to explore the distributed ledger technology adoption in energy management [8]. There are movements toward proper implementations of renewable energy sources [5], and the adoption of distributed ledger technology is reflected by having an optimistic opening to be economical worldwide [142]. The distributed ledger technology implementation should bring a reduction in cost and ease for clients for consumption [44]. By virtue of the benefits, distributed ledgers could advance energy cybersecurity, and in turn as a backup technology, which can advance the privacy of the supply, conclusively encouraging sustainability through aiding renewable generation with a low-carbon solution.

\subsection{Limitations and Conclusions}

Just like other studies, there are also some limitations in the current study. Firstly, the present study was conducted only in the energy management in one country. For the coming future, we may take neighbor technology-advanced countries like a cross-sectional study with China. The results of such a study will be more interesting. Secondly, the current study integrated the TAM constructs (perceived ease of use, perceived usefulness, attitude, and behavioral intention) with cost saving and innovativeness. In the future, we may integrate with other traditional adoption theories like TAM with the theory of planned behavior. The result of such a study will be more interesting. Third, blockchain is not a standalone technology. In the current study, we did not integrate the distributed ledger technology with other technologies. In the future, we may integrate with other technologies like the internet of things. The findings of such studies will be more helpful for the organizations. Fourth, few studies have been conducted on the cost related to distributed ledger technology adoption apart from protype research [141]. In the future, further research is required on similar technology, as companies that plan to integrate distributed ledger technology into their traditional trade would require more attention on the need for it.

In conclusion, the current study expands the technology acceptance model constructs with cost and innovativeness for the acceptance of blockchains in the energy management. In response to RQ1, based on the results, it is confirmed that the perceived ease of use, perceived usefulness, and attitude with cost saving show a positive effect on the user's intention to accept disruptive technology for energy management. However, innovativeness shows a significant effect on the perceived ease of use while an insignificant effect on the perceived usefulness. Pertaining to RQ2, the study findings show that the perceived ease of use matters most in the implementation of blockchain. Moreover, an important role of this research is that most technology adoption approaches have been studied in developed states [143]. Therefore, this study is unique to the such context. The current study offers a holistic model for the implementation of innovative technologies. For the developers, it suggests precious visions for increasing disruptive technology solutions. The adoption of distributed ledger technology for regional energy marketplaces in P2P will provide a solution for regional energy system optimization that can reduce the power network strain or delay costly strengthening. Additionally, 
domestic markets might deliver extra revenue sources for RES produces and could possibly reduce the energy cost for end consumers.

Author Contributions: Conceptualization, W.M.A.-R., W.S.A., A.I.A. and N.U.; methodology, N.U., A.I.A., H.A.-S. and W.M.A.-R.; software, W.M.A.-R. and N.U.; formal analysis, N.U., W.M.A.-R., W.S.A. and A.I.A.; resources, N.U. and W.M.A.-R.; writing — original draft preparation, W.S.A., A.I.A. and N.U.; writing—review and editing, W.M.A.-R., W.S.A., A.I.A., H.A.-S. and N.U.; Supervisor, W.M.A.-R., W.S.A., A.I.A. and H.A.-S. All authors have read and agreed to the published version of the manuscript.

Funding: This work was funded by the Researcher Supporting Project (RSP-2020/250), King Saud University, Riyadh, Saudi Arabia.

Acknowledgments: This work was funded by the Researcher Supporting Project (RSP-2020/250), King Saud University, Riyadh, Saudi Arabia.

Conflicts of Interest: The authors declare no conflict of interest.

\section{References}

1. Jiang, Y. Total factor productivity, pollution and 'green'economic growth in China. J. Int. Dev. 2015, 27, 504-515. [CrossRef]

2. Chen, C.; Lan, Q.; Gao, M.; Sun, Y. Green total factor productivity growth and its determinants in China's industrial economy. Sustainability 2018, 10, 1052. [CrossRef]

3. Brilliantova, V.; Thurner, T.W. Blockchain and the future of energy. Technol. Soc. 2019, 57, 38-45. [CrossRef]

4. Kamran, M.; Fazal, M.R.; Mudassar, M. Towards empowerment of the renewable energy sector in Pakistan for sustainable energy evolution: SWOT analysis. Renew. Energy 2020, 146, 543-558. [CrossRef]

5. Solangi, Y.A.; Tan, Q.; Mirjat, N.H.; Ali, S. Evaluating the strategies for sustainable energy planning in Pakistan: An integrated SWOT-AHP and Fuzzy-TOPSIS approach. J. Clean. Prod. 2019, 236, 117655. [CrossRef]

6. Zhang, Y.-J.; Hao, J.-F. Carbon emission quota allocation among China's industrial sectors based on the equity and efficiency principles. Ann. Oper. Res. 2017, 255, 117-140. [CrossRef]

7. Di Silvestre, M.L.; Gallo, P.; Guerrero, J.M.; Musca, R.; Sanseverino, E.R.; Sciumè, G.; Vásquez, J.C.; Zizzo, G. Blockchain for power systems: Current trends and future applications. Renew. Sustain. Energy Rev. 2020, 119, 109585. [CrossRef]

8. Ahl, A.; Yarime, M.; Goto, M.; Chopra, S.S.; Kumar, N.M.; Tanaka, K.; Sagawa, D. Exploring blockchain for the energy transition: Opportunities and challenges based on a case study in Japan. Renew. Sustain. Energy Rev. 2020, 117, 109488. [CrossRef]

9. Ruben, R.B.; Vinodh, S.; Asokan, P. Implementation of Lean Six Sigma framework with environmental considerations in an Indian automotive component manufacturing firm: A case study. Prod. Plan. Control 2017, 28, 1193-1211. [CrossRef]

10. Hansen, P.; Liu, X.; Morrison, G. Agent-based modelling and socio-technical energy transitions: A systematic literature review. Energy Res. Soc. Sci. 2019, 49, 41-52. [CrossRef]

11. Bheemaiah, K. The Blockchain Alternative: Rethinking Macroeconomic Policy and Economic Theory; Apress: New York, NY, USA, 2017.

12. Griffoli, T.M.; Peria, M.M.; Agur, I.; Ari, A.; Kiff, J.; Popescu, A.; Rochon, C. Casting light on central bank digital currency. IMF Staff Discuss. Notes 2018. [CrossRef]

13. Andoni, M.; Robu, V.; Flynn, D.; Abram, S.; Geach, D.; Jenkins, D.; McCallum, P.; Peacock, A.D. Blockchain technology in the energy sector: A systematic review of challenges and opportunities. Renew. Sustain. Energy Rev. 2019, 100, 143-174. [CrossRef]

14. Camarinha-Matos, L.M. Collaborative smart grids-A survey on trends. Renew. Sustain. Energy Rev. 2016, 65, 283-294. [CrossRef]

15. Wu, J.; Tran, N.K. Application of blockchain technology in sustainable energy systems: An overview. Sustainability 2018, 10, 3067. [CrossRef]

16. Mengelkamp, E.; Gärttner, J.; Rock, K.; Kessler, S.; Orsini, L.; Weinhardt, C. Designing microgrid energy markets: A case study: The Brooklyn Microgrid. Appl. Energy 2018, 210, 870-880. [CrossRef] 
17. Sabounchi, M.; Wei, J. Towards resilient networked microgrids: Blockchain-enabled peer-to-peer electricity trading mechanism. In Proceedings of the 2017 IEEE Conference on Energy Internet and Energy System Integration (EI2), Beijing, China, 26-28 November 2017; pp. 1-5.

18. Mingxiao, D.; Xiaofeng, M.; Zhe, Z.; Xiangwei, W.; Qijun, C. A review on consensus algorithm of blockchain. In Proceedings of the 2017 IEEE International Conference on Systems, Man, and Cybernetics (SMC), Banff, AB, Canada, 5-8 October 2017; pp. 2567-2572.

19. Cohn, A.; West, T.; Parker, C. Smart after all: Blockchain, smart contracts, parametric insurance, and smart energy grids. Georget. Law Technol. Rev. 2017, 1, 273-304.

20. Teufel, B.; Sentic, A.; Barmet, M. Blockchain energy: Blockchain in future energy systems. J. Electr. Sci. Technol. 2019, 17, 100011. [CrossRef]

21. Miraz, M.H.; Ali, M. Applications of blockchain technology beyond cryptocurrency. arXiv 2018, arXiv:1801.03528. [CrossRef]

22. Szabo, N. Formalizing and securing relationships on public networks. First Monday 1997. [CrossRef]

23. Li, Y.; Yang, W.; He, P.; Chen, C.; Wang, X. Design and management of a distributed hybrid energy system through smart contract and blockchain. Appl. Energy 2019, 248, 390-405. [CrossRef]

24. Cali, U.; Fifield, A. Towards the decentralized revolution in energy systems using blockchain technology. Int. J. Smart Grid Clean Energy 2019, 8, 245-256. [CrossRef]

25. Zhao, Y.; Peng, K.; Xu, B.; Liu, Y.; Xiong, W.; Han, Y. Applied engineering programs of energy blockchain in US. Energy Proc. 2019, 158, 2787-2793. [CrossRef]

26. Albrecht, S.; Reichert, S.; Schmid, J.; Strüker, J.; Neumann, D.; Fridgen, G. Dynamics of blockchain implementation-a case study from the energy sector. In Proceedings of the 51st Hawaii International Conference on System Sciences, Waikoloa Village, HI, USA, 3-6 January 2018.

27. Davis, F.D. Perceived usefulness, perceived ease of use, and user acceptance of information technology. MIS Quart. 1989, 319-340. [CrossRef]

28. Globerson, S.; Maggard, M.J. A conceptual model of self-service. Int. J. Oper. Prod. Manag. 1991. [CrossRef]

29. Parasuraman, A. Technology Readiness Index (TRI) a multiple-item scale to measure readiness to embrace new technologies. J. Serv. Res. 2000, 2, 307-320. [CrossRef]

30. Nakamoto, S. Re: Bitcoin P2P e-cash paper. In The Cryptography Mailing List; Nakamoto Institute: Austin, TX, USA, 2008.

31. Lin, I.-C.; Liao, T.-C. A survey of blockchain security issues and challenges. IJ Netw. Secur. 2017, 19, 653-659.

32. Bashir, I. Mastering Blockchain: Distributed Ledger Technology, Decentralization, and Smart Contracts Explained; Packt Publishing Ltd.: Birmingham, UK, 2018.

33. Ølnes, S.; Ubacht, J.; Janssen, M. Blockchain in Government: Benefits and Implications of Distributed Ledger Technology for Information Sharing; Elsevier: Amsterdam, The Netherlands, 2017.

34. Bettio, M.; Bruse, F.; Franke, A.; Jakoby, T.; Schärf, D. Hyperledger fabric as a blockchain framework in the financial industry. In The Impact of Digital Transformation and FinTech on the Finance Professional; Springer: Berlin, Germany, 2019; pp. 29-44.

35. Cong, L.W.; He, Z. Blockchain disruption and smart contracts. Rev. Financ. Stud. 2019, 32, $1754-1797$. [CrossRef]

36. Levy, K.E. Book-smart, not street-smart: Blockchain-based smart contracts and the social workings of law. Engag. Sci. Technol. Soc. 2017, 3, 1-15. [CrossRef]

37. Sun, M.; Zhang, J. Research on the application of block chain big data platform in the construction of new smart city for low carbon emission and green environment. Comp. Commun. 2020, 149, 332-342. [CrossRef]

38. Thakre, A.; Thabtah, F.; Shahamiri, S.R.; Hammoud, S. A novel block chain technology publication model proposal. Appl. Comput. Inf. 2019. [CrossRef]

39. Tapscott, A.; Tapscott, D. How blockchain is changing finance. Harv. Bus. Rev. 2017, 1, $2-5$.

40. Macrinici, D.; Cartofeanu, C.; Gao, S. Smart contract applications within blockchain technology: A systematic mapping study. Telemat. Inf. 2018, 35, 2337-2354. [CrossRef]

41. Tang, H.; Shi, Y.; Dong, P. Public blockchain evaluation using entropy and TOPSIS. Exp. Syst. Appl. 2019, 117, 204-210. [CrossRef]

42. Wright, A.; De Filippi, P. Decentralized blockchain technology and the rise of lex cryptographia. SSRN 2015. [CrossRef] 
43. Lund, H.; Mathiesen, B.V. Energy system analysis of $100 \%$ renewable energy systems-The case of Denmark in years 2030 and 2050. Energy 2009, 34, 524-531. [CrossRef]

44. Zhu, S.; Song, M.; Lim, M.K.; Wang, J.; Zhao, J. The development of energy blockchain and its implications for China's energy sector. Resour. Policy 2020, 66, 101595. [CrossRef]

45. Sikorski, J.J.; Haughton, J.; Kraft, M. Blockchain technology in the chemical industry: Machine-to-machine electricity market. Appl. Energy 2017, 195, 234-246. [CrossRef]

46. Pop, C.; Cioara, T.; Antal, M.; Anghel, I.; Salomie, I.; Bertoncini, M. Blockchain based decentralized management of demand response programs in smart energy grids. Sensors 2018, 18, 162. [CrossRef]

47. Mollah, M.B.; Zhao, J.; Niyato, D.; Lam, K.-Y.; Zhang, X.; Ghias, A.M.; Koh, L.H.; Yang, L. Blockchain for future smart grid: A comprehensive survey. IEEE Internet Things J. 2020. [CrossRef]

48. Thakur, S.; Breslin, J.G. Peer to peer energy trade among microgrids using blockchain based distributed coalition formation method. Technol. Econ. Smart Grids Sustain. Energy 2018, 3, 5. [CrossRef]

49. Su, Z.; Wang, Y.; Xu, Q.; Fei, M.; Tian, Y.-C.; Zhang, N. A secure charging scheme for electric vehicles with smart communities in energy blockchain. IEEE Internet Things J. 2018, 6, 4601-4613. [CrossRef]

50. Mengelkamp, E.; Notheisen, B.; Beer, C.; Dauer, D.; Weinhardt, C. A blockchain-based smart grid: Towards sustainable local energy markets. Comp. Sci. Res. Dev. 2018, 33, 207-214. [CrossRef]

51. Elmustapha, H.; Hoppe, T.; Bressers, H. Consumer renewable energy technology adoption decision-making; comparing models on perceived attributes and attitudinal constructs in the case of solar water heaters in Lebanon. J. Clean. Prod. 2018, 172, 347-357. [CrossRef]

52. Cho, Y.; Shaygan, A.; Daim, T.U. Energy technology adoption: Case of solar photovoltaic in the Pacific Northwest USA. Sustain. Energy Technol. Assess. 2019, 34, 187-199. [CrossRef]

53. Mejia, M.A.; Melo, J.D.; Zambrano-Asanza, S.; Padilha-Feltrin, A. Spatial-temporal growth model to estimate the adoption of new end-use electric technologies encouraged by energy-efficiency programs. Energy 2020, 191, 116531. [CrossRef]

54. Szajna, B. Empirical evaluation of the revised technology acceptance model. Manag. Sci. 1996, 42, 85-92. [CrossRef]

55. Lu, J.; Yu, C.S.; Liu, C.; Yao, J.E. Technology acceptance model for wireless Internet. Internet Res. 2003. [CrossRef]

56. Pavlou, P.A. Consumer acceptance of electronic commerce: Integrating trust and risk with the technology acceptance model. Int. J. Electron. Commerce 2003, 7, 101-134.

57. Larasati, N.; Santosa, P.I. Technology readiness and technology acceptance model in new technology implementation process in low technology SMEs. Int. J. Innov. Manag. Technol. 2017, 8, 113. [CrossRef]

58. Venkatesh, V.; Davis, F.D. A theoretical extension of the technology acceptance model: Four longitudinal field studies. Manag. Sci. 2000, 46, 186-204. [CrossRef]

59. Rezaei, R.; Ghofranfarid, M. Rural households' renewable energy usage intention in Iran: Extending the unified theory of acceptance and use of technology. Renew. Energy 2018, 122, 382-391. [CrossRef]

60. Yoon, C. Extending the TAM for Green IT: A normative perspective. Comp. Hum. Behav. 2018, 83, 129-139. [CrossRef]

61. Zhao, Q.; Chen, C.-D.; Wang, J.-L. The effects of psychological ownership and TAM on social media loyalty: An integrated model. Telemat. Inf. 2016, 33, 959-972. [CrossRef]

62. Grover, P.; Kar, A.K.; Janssen, M.; Ilavarasan, P.V. Perceived usefulness, ease of use and user acceptance of blockchain technology for digital transactions-insights from user-generated content on Twitter. Enterp. Inf. Syst. 2019, 13, 771-800. [CrossRef]

63. Al-Rahmi, W.M.; Alzahrani, A.I.; Yahaya, N.; Alalwan, N.; Kamin, Y.B. Digital Communication: Information and Communication Technology (ICT) Usage for Education Sustainability. Sustainability 2020, 12, 5052. [CrossRef]

64. Tumasjan, A.; Beutel, T. Blockchain-based decentralized business models in the sharing economy: A technology adoption perspective. In Business Transformation through Blockchain; Springer: Berlin, Germany, 2019; pp. 77-120.

65. Nuryyev, G.; Wang, Y.-P.; Achyldurdyyeva, J.; Jaw, B.-S.; Yeh, Y.-S.; Lin, H.-T.; Wu, L.-F. Blockchain Technology Adoption Behavior and Sustainability of the Business in Tourism and Hospitality SMEs: An Empirical Study. Sustainability 2020, 12, 1256. [CrossRef] 
66. Schuetz, S.; Venkatesh, V. Blockchain, adoption, and financial inclusion in India: Research opportunities. Int. J. Inf. Manag. 2020, 52, 101936. [CrossRef]

67. Davis, F.D.; Bagozzi, R.P.; Warshaw, P.R. User acceptance of computer technology: A comparison of two theoretical models. Manag. Sci. 1989, 35, 982-1003. [CrossRef]

68. Ho, S.H.; Ko, Y.Y. Effects of self-service technology on customer value and customer readiness. Internet Res. 2008. [CrossRef]

69. Pattansheti, M.; Kamble, S.S.; Dhume, S.M.; Raut, R.D. Development, measurement and validation of an integrated technology readiness acceptance and planned behaviour model for Indian mobile banking industry. Int. J. Bus. Inf. Syst. 2016, 22, 316-342.

70. Yang, H.-D.; Yoo, Y. It's all about attitude: Revisiting the technology acceptance model. Decis. Support Syst. 2004, 38, 19-31. [CrossRef]

71. Kleijnen, M.; Wetzels, M.; De Ruyter, K. Consumer acceptance of wireless finance. J. Financ. Serv. Mark. 2004, 8, 206-217. [CrossRef]

72. Wamba, S.F.; Queiroz, M.M.; Trinchera, L. Dynamics between blockchain adoption determinants and supply chain performance: An empirical investigation. Int. J. Prod. Econ. 2020, 107791. [CrossRef]

73. Alamri, M.M.; Almaiah, M.A.; Al-Rahmi, W.M. Social Media Applications Affecting Students' Academic Performance: A Model Developed for Sustainability in Higher Education. Sustainability 2020, 12, 6471. [CrossRef]

74. Chen, S.; Chen, H. The influence of technology readiness on the theory of planned behavior with self-service technologies. In Proceedings of the WMSCI The 12th World Multi-Conference on Systemics, Cybernetics and Informatics, Orlando, FL, USA, 29 June-2 July 2008; Volume 6, pp. 85-90.

75. Wang, Y.S.; Wang, Y.M.; Lin, H.H.; Tang, T.I. Determinants of user acceptance of Internet banking: An empirical study. Int. J. Serv. Ind. Manag. 2003. [CrossRef]

76. Karamchandani, A.; Srivastava, S.K.; Srivastava, R.K. Perception-based model for analyzing the impact of enterprise blockchain adoption on SCM in the Indian service industry. Int. J. Inf. Manag. 2019, 102019. [CrossRef]

77. Venkatesh, V.; Morris, M.G.; Davis, G.B.; Davis, F.D. User acceptance of information technology: Toward a unified view. MIS Q. 2003, 27, 425-478. [CrossRef]

78. Folkinshteyn, D.; Lennon, M. Braving Bitcoin: A technology acceptance model (TAM) analysis. J. Inf. Technol. Case Appl. Res. 2016, 18, 220-249. [CrossRef]

79. Guriting, P.; Ndubisi, N.O. Borneo online banking: Evaluating customer perceptions and behavioural intention. Manag. Res. News 2006. [CrossRef]

80. Ajzen, I.; Fishbein, M. Handbook of Attitudes; Albarracín, D., Johnson, B.T., Zanna, M.P., Eds.; Erlbaum: Mahwah, NJ, USA, 2005.

81. Taylor, S.; Todd, P.A. Understanding information technology usage: A test of competing models. Inf. Syst. Res. 1995, 6, 144-176. [CrossRef]

82. Agarwal, R.; Prasad, J. The antecedents and consequents of user perceptions in information technology adoption. Decis. Support Syst. 1998, 22, 15-29. [CrossRef]

83. Gefen, D.; Karahanna, E.; Straub, D.W. Inexperience and experience with online stores: The importance of TAM and trust. IEEE Trans. Eng. Manag. 2003, 50, 307-321. [CrossRef]

84. Kamble, S.; Gunasekaran, A.; Arha, H. Understanding the Blockchain technology adoption in supply chains-Indian context. Int. J. Prod. Res. 2019, 57, 2009-2033. [CrossRef]

85. Ding, X.; Verma, R.; Iqbal, Z. Self-service technology and online financial service choice. Int. J. Serv. Ind. Manag. 2007. [CrossRef]

86. Meuter, M.L.; Ostrom, A.L.; Roundtree, R.I.; Bitner, M.J. Self-service technologies: Understanding customer satisfaction with technology-based service encounters. J. Mark. 2000, 64, 50-64. [CrossRef]

87. Howard, M.; Worboys, C. Self-service-a contradiction in terms or customer-led choice? J. Consum. Behav. Int. Res. Rev. 2003, 2, 382-392. [CrossRef]

88. Maggard, M.; Globerson, S. Employee Cross-Training: A Corporate Strategy for Increasing Productivity. In Toward the Factory of the Future; Springer: Berlin, Germany, 1985; p. 948.

89. Kim, S.H. Moderating effects of job relevance and experience on mobile wireless technology acceptance: Adoption of a smartphone by individuals. Inf. Manag. 2008, 45, 387-393. [CrossRef] 
90. Museli, A.; Navimipour, N.J. A model for examining the factors impacting the near field communication technology adoption in the organizations. Kybernetes 2018. [CrossRef]

91. Tashkandi, A.N.; Al-Jabri, I.M. Cloud computing adoption by higher education institutions in Saudi Arabia: An exploratory study. Cluster Comput. 2015, 18, 1527-1537. [CrossRef]

92. Swan, M. Blockchain: Blueprint for a New Economy; O’Reilly Media, Inc.: Newton, MA, USA, 2015.

93. Vasseur, V.; Kemp, R. The adoption of PV in the Netherlands: A statistical analysis of adoption factors. Renew. Sustain. Energy Rev. 2015, 41, 483-494. [CrossRef]

94. Gallardo, G.; Hernantes, J.; Serrano, N. Designing SaaS for enterprise adoption based on task, company, and value-chain context. IEEE Internet Comput. 2018, 22, 37-45. [CrossRef]

95. Godoe, P.; Johansen, T. Understanding adoption of new technologies: Technology readiness and technology acceptance as an integrated concept. J. Eur. Psychol. Stud. 2012, 3, 1. [CrossRef]

96. Walczuch, R.; Lemmink, J.; Streukens, S. The effect of service employees' technology readiness on technology acceptance. Inf. Manag. 2007, 44, 206-215. [CrossRef]

97. Yi, Y.; Tung, L.L.; Wu, Z. Incorporating Technology Readiness (TR) into TAM: Are Individual Traits Important to Understand Technology Acceptance? DIGIT 2003 Proc. 2003, p. 2. Available online: https: //aisel.aisnet.org/digit2003/2/ (accessed on 7 May 2020).

98. Sun, S.; Cegielski, C.G.; Jia, L.; Hall, D.J. Understanding the factors affecting the organizational adoption of big data. J. Comp. Inf. Syst. 2018, 58, 193-203. [CrossRef]

99. Yoon, J.; Talluri, S.; Yildiz, H.; Sheu, C. The value of Blockchain technology implementation in international trades under demand volatility risk. Int. J. Prod. Res. 2020, 58, 2163-2183. [CrossRef]

100. Kuo, K.-M.; Liu, C.-F.; Ma, C.-C. An investigation of the effect of nurses' technology readiness on the acceptance of mobile electronic medical record systems. BMC Med. Inform. Decis. Mak. 2013, $13,88$. [CrossRef]

101. Allen, I.E.; Seaman, C.A. Likert scales and data analyses. Qual. Prog. 2007, 40, 64-65.

102. Croasmun, J.T.; Ostrom, L. Using Likert-Type Scales in the Social Sciences. J. Adult Educ. 2011, 40, 19-22.

103. Bentler, P.M.; Chou, C.-P. Practical issues in structural modeling. Sociol. Methods Res. 1987, 16, 78-117. [CrossRef]

104. Sideridis, G.; Simos, P.; Papanicolaou, A.; Fletcher, J. Using structural equation modeling to assess functional connectivity in the brain: Power and sample size considerations. Educ. Psychol. Meas. 2014, 74, 733-758. [CrossRef]

105. Chin, W.W. The partial least squares approach to structural equation modeling. Modern Methods Bus. Res. 1998, 295, 295-336.

106. Lowry, P.B.; Gaskin, J. Partial least squares (PLS) structural equation modeling (SEM) for building and testing behavioral causal theory: When to choose it and how to use it. IEEE Trans. Prof. Commun. 2014, 57, 123-146. [CrossRef]

107. Hwang, H.; Malhotra, N.K.; Kim, Y.; Tomiuk, M.A.; Hong, S. A comparative study on parameter recovery of three approaches to structural equation modeling. J. Mark. Res. 2010, 47, 699-712. [CrossRef]

108. Hair, J.F.; Ringle, C.M.; Sarstedt, M. PLS-SEM: Indeed a silver bullet. J. Mark. Theory Pract. 2011, 19, $139-152$. [CrossRef]

109. Alalwan, N.; Al-Rahmi, W.M.; Alfarraj, O.; Alzahrani, A.; Yahaya, N.; Al-Rahmi, A.M. Integrated Three Theories to Develop a Model of Factors Affecting Students' Academic Performance in Higher Education. IEEE Access 2019, 7, 98725-98742. [CrossRef]

110. Warkentin, M.; Sharma, S.; Gefen, D.; Rose, G.M.; Pavlou, P. Social identity and trust in internet-based voting adoption. Govern. Inf. Quart. 2018, 35, 195-209. [CrossRef]

111. Alenazy, W.M.; Al-Rahmi, W.M.; Khan, M.S. Validation of TAM model on social media use for collaborative learning to enhance collaborative authoring. IEEE Access 2019, 7, 71550-71562. [CrossRef]

112. Aboelmaged, M.; Gebba, T.R. Mobile banking adoption: An examination of technology acceptance model and theory of planned behavior. Int. J. Bus. Res. Dev. 2013, 2, 1. [CrossRef]

113. Wong, L.-W.; Leong, L.-Y.; Hew, J.-J.; Tan, G.W.-H.; Ooi, K.-B. Time to seize the digital evolution: Adoption of blockchain in operations and supply chain management among Malaysian SMEs. Int. J. Inform. Manag. 2020, 52, 101997. [CrossRef] 
114. Al-Rahmi, W.M.; Yahaya, N.; Aldraiweesh, A.A.; Alturki, U.; Alamri, M.M.; Saud, M.S.B.; Kamin, Y.B.; Alhamed, O.A. Big data adoption and knowledge management sharing: An empirical investigation on their adoption and sustainability as a purpose of education. IEEE Access 2019, 7, 47245-47258. [CrossRef]

115. Lilliefors, H.W. On the Kolmogorov-Smirnov test for normality with mean and variance unknown. J. Am. Stat. Assoc. 1967, 62, 399-402. [CrossRef]

116. Ryans, A.B. Estimating consumer preferences for a new durable brand in an established product class. J. Mark. Res. 1974, 11, 434-443. [CrossRef]

117. Wallace, R.O.; Mellor, C. Nonresponse bias in mail accounting surveys: A pedagogical note. Br. Account. Rev. 1988, 20, 131-139. [CrossRef]

118. Oppenheim, A. Questionnaire Design and Attitude Measurement Heinemann; Continuum: London, UK, 1966.

119. Tan, G.W.-H.; Lee, V.-H.; Hew, J.-J.; Ooi, K.-B.; Wong, L.-W. The interactive mobile social media advertising: An imminent approach to advertise tourism products and services? Telemat. Inform. 2018, 35, 2270-2288. [CrossRef]

120. Wong, C.-H.; Tan, G.W.-H.; Tan, B.-I.; Ooi, K.-B. Mobile advertising: The changing landscape of the advertising industry. Telemat. Inform. 2015, 32, 720-734. [CrossRef]

121. Chuah, S.H.-W.; Marimuthu, M.; Kandampully, J.; Bilgihan, A. What drives Gen Y loyalty? Understanding the mediated moderating roles of switching costs and alternative attractiveness in the value-satisfaction-loyalty chain. J. Retail. Consum. Serv. 2017, 36, 124-136. [CrossRef]

122. Hair, J.F., Jr.; Hult, G.T.M.; Ringle, C.; Sarstedt, M. A Primer on Partial Least Squares Structural Equation Modeling (PLS-SEM); Sage Publications: Thousand Oaks, CA, USA, 2016.

123. Fornell, C.; Larcker, D.F. Structural Equation Models with Unobservable Variables and Measurement Error: Algebra and Statistics; Sage Publications Sage CA: Los Angeles, CA, USA, 1981.

124. Wong, K.K.-K. Partial least squares structural equation modeling (PLS-SEM) techniques using SmartPLS. Mark. Bull. 2013, 24, 1-32.

125. Xie, Q.; Song, W.; Peng, X.; Shabbir, M. Predictors for e-government adoption: Integrating TAM, TPB, trust and perceived risk. Electron. Libr. 2017, 35, 2-20. [CrossRef]

126. López-Nicolás, C.; Molina-Castillo, F.J.; Bouwman, H. An assessment of advanced mobile services acceptance: Contributions from TAM and diffusion theory models. Inf. Manag. 2008, 45, 359-364. [CrossRef]

127. Aboelmaged, M.G. Predicting e-procurement adoption in a developing country. Ind. Manag. Data Syst. 2010. [CrossRef]

128. Chen, J.V.; Yen, D.C.; Chen, K. The acceptance and diffusion of the innovative smart phone use: A case study of a delivery service company in logistics. Inf. Manag. 2009, 46, 241-248. [CrossRef]

129. Amoako-Gyampah, K.; Salam, A.F. An extension of the technology acceptance model in an ERP implementation environment. Inf. Manag. 2004, 41, 731-745. [CrossRef]

130. Bröhl, C.; Nelles, J.; Brandl, C.; Mertens, A.; Schlick, C.M. TAM Reloaded: A Technology Acceptance Model for Human-Robot Cooperation in Production Systems. In Proceedings of the International Conference on Human-Computer Interaction, Aachen, Germany, 2-4 March 2016; Springer: Berlin, Germany; pp. 97-103.

131. Gao, L.; Bai, X. A unified perspective on the factors influencing consumer acceptance of internet of things technology. Asia Pac. J. Mark. Logist. 2014. [CrossRef]

132. Lee, M.S. An empirical study about RFID acceptance-Focus on the employees in Korea. Int. J. Bus. Econ. Finance Manag. Sci. 2009, 1, 1539-1548.

133. Moon, J.-W.; Kim, Y.-G. Extending the TAM for a World-Wide-Web context. Inform. Manag. 2001, 38, $217-230$. [CrossRef]

134. Shih, B.-Y.; Chen, C.-Y.; Chen, C.-L. An enhanced acceptance model for exploring user intention towards virtual reality environment: Partial least squares (PLS) statistical method. Int. J. Phys. Sci. 2012, 7, 776-786.

135. Chau, P.Y.; Hu, P.J.-H. Investigating healthcare professionals' decisions to accept telemedicine technology: An empirical test of competing theories. Inform. Manag. 2002, 39, 297-311. [CrossRef]

136. Alalwan, A.A.; Baabdullah, A.M.; Rana, N.P.; Tamilmani, K.; Dwivedi, Y.K. Examining adoption of mobile internet in Saudi Arabia: Extending TAM with perceived enjoyment, innovativeness and trust. Technol. Soc. 2018, 55, 100-110. [CrossRef]

137. Mylrea, M.; Gourisetti, S.N.G. Blockchain for smart grid resilience: Exchanging distributed energy at speed, scale and security. In Proceedings of the 2017 Resilience Week (RWS), Wilmington, DE, USA, 18-22 September 2017; pp. 18-23. 
138. Oosterhuis, M.; Van der Vaart, T.; Molleman, E. Perceptions of technology uncertainty and the consequences for performance in buyer-supplier relationships. Int. J. Prod. Res. 2011, 49, 6155-6173. [CrossRef]

139. Ying, W.; Jia, S.; Du, W. Digital enablement of blockchain: Evidence from HNA group. Int. J. Inform. Manag. 2018, 39, 1-4. [CrossRef]

140. Lu, Y. The blockchain: State-of-the-art and research challenges. J. Ind. Inf. Integr. 2019. [CrossRef]

141. Hughes, L.; Dwivedi, Y.K.; Misra, S.K.; Rana, N.P.; Raghavan, V.; Akella, V. Blockchain research, practice and policy: Applications, benefits, limitations, emerging research themes and research agenda. Int. J. Inform. Manag. 2019, 49, 114-129. [CrossRef]

142. Tapscott, D.; Tapscott, A. How blockchain will change organizations. MIT Sloan Manag. Rev. 2017, 58, 10.

143. Imran, A.; Gregor, S. A comparative analysis of strategies for egovernment in developing countries. J. Law Govern. 2007, 2, 3. [CrossRef]

(C) 2020 by the authors. Licensee MDPI, Basel, Switzerland. This article is an open access article distributed under the terms and conditions of the Creative Commons Attribution (CC BY) license (http://creativecommons.org/licenses/by/4.0/). 